\title{
PRICE needs updating, should we call the POLICE?
}

C M Bleakley, ${ }^{1,3}$ P Glasgow, ${ }^{2,3}$ D C MacAuley ${ }^{4}$

The acronym PRICE (protection, rest, ice, compression and elevation) has been central to acute soft tissue injury management for many years despite a paucity of highquality, empirical evidence to support the various components or as a collective treatment package. Treatment paradigms in sports medicine must be updated based on contemporary research evidence. As a recent example, the widespread use of non-steroidal anti-inflammatory drugs in acute soft tissue injury management has been challenged, particularly with ligament and muscle injuries. ${ }^{1}$

Ice compression and elevation (ICE) is the basic principle of early treatment. Most research has focused on the analgesic effect of icing or the associated skin or intramuscular temperature changes; a recent randomised controlled trial by Prins and colleagues, ${ }^{2}$ which examined the effectiveness of ice on recovery from acute muscle tear, is the first of its kind. Clinical studies into compression are also lacking, and much of its rationale is extrapolated from research relating to deep venous thrombosis prophylaxis and lymphoedema management; there is little clinical research on elevation. ${ }^{3}$

Protection and rest after injury are supported by interventions that stress shield, unload and/or prevent joint movement for various periods. Recent animal models ${ }^{4-6}$ show that short periods of unloading are required after acute soft tissue injury and that aggressive ambulation or exercise should be avoided. But, rest should be of limited duration and restricted to immediately after trauma. Longer periods of unloading are harmful and produce adverse changes to tissue biomechanics

\footnotetext{
${ }^{1}$ Health and Rehabilitation Sciences Research Institute, University of Ulster, Jordanstown, Newtownabbey, UK ${ }^{2}$ Sports Institute of Northern Ireland, University of Ulster, Jordanstown, Newtownabbey, UK

${ }^{3}$ Association of Physiotherapists in Sports and Exercise Medicine, London, UK

${ }^{4}$ UKCRC Centre of Excellence for Public Health (NI), Queens University Belfast, Royal Victoria Hospital, Belfast, UK
}

Correspondence to C M Bleakley, Health and Rehabilitation Sciences Research Institute, University of Ulster, Jordanstown, Newtownabbey, County Antrim BT3700B, UK; chrisbleakley@hotmail.com and morphology. Progressive mechanical loading is more likely to restore the strength and morphological characteristics of collagenous tissue. ${ }^{4}$ Indeed, early mobilisation with accelerated rehabilitation is effective after acute ankle strain. ${ }^{7}$ Functional rehabilitation of ankle sprain, which involves early weight-bearing usually with an external support, is superior to cast immobilisation for most types of sprain severity. 89

Functional rehabilitation aligns well with the principles of mechanotherapy, whereby mechanical loading prompts cellular responses that promote tissue structural change. ${ }^{10}$ There are consistent findings from animal models that demonstrate how mechanical loading upregulates mRNA expression for key proteins associated with soft tissue healing. ${ }^{4-6}$ The difficult clinical challenge is finding the balance between loading and unloading during tissue healing. If tissues are stressed too aggressively after injury, the mechanical insult may cause re-bleeding or further damage. Protection of vulnerable tissues therefore remains an important principle. But, too much emphasis creates a default mindset that loading has no place in acute management. Rest may be harmful and inhibits recovery. The secret is to find the 'optimal loading'.

Optimal loading means replacing rest with a balanced and incremental rehabilitation programme where early activity encourages early recovery. Injuries vary so there is no single one size fits all strategy or dosage. A loading strategy should reflect the unique mechanical stresses placed upon the injured tissue during functional activities, which varies across tissue type and anatomical region. For example, a muscle injury to the lower limb has cyclic loading through normal ambulation. The upper limb may require additional cyclic load to be factored into the rehabilitation program in order to maximise mechanical stimulus.

POLICE, a new acronym, which represents protection, optimal loading, ice compression and elevation, is not simply a formula but a reminder to clinicians to think differently and seek out new and innovative strategies for safe and effective loading in acute soft tissue injury management. Optimal loading is an umbrella term for any mechanotherapy intervention and includes a wide range of manual techniques currently available; indeed the term may include manual techniques such as massage refined to maximise the mechano-effect. Paradoxically, crutches, braces and supports, traditionally associated with rest, may have a greater role in adjusting and regulating optimal loading in the early stages of rehabilitation.

POLICE should make us think more about research into designing rehabilitation strategies that are appropriate to the nature and severity of injury in different sports and activities. If the primary principle of treatment is to restore the histologi$\mathrm{cal}$ and mechanical properties of injured soft tissue, optimal loading may indeed be sport specific. The challenge is in determining what is 'optimal' in terms of the dosage, nature and timing.

POLICE is not just an acronym to guide management but a stimulus to a new field of research. It is important that this research includes more rigorous examination of the role of ICE in acute injury management. Currently, cold-induced analgesia and the assurance and support provided by compression and elevation are enough to retain ICE within the acronym.

\section{Competing interests None.}

Provenance and peer review Not commissioned; externally peer reviewed.

Accepted 3 August 2011

\section{REFERENCES}

1. Paoloni JA, Milne C, Orchard J, et al. Nonsteroidal anti-inflammatory drugs in sports medicine: guidelines for practical but sensible use. Br J Sports Med 2009;43:863-5.

2. Prins JC, Stubbe JH, van Meeteren NL, et al. Feasibility and preliminary effectiveness of ice therapy in patients with an acute tear in the gastrocnemius muscle: a pilot randomized controlled trial. Clin Rehabil 2011;25:433-41.

3. Bleakley CM, Glasgow PD, Philips P, et al; for the Association of Chartered Physiotherapists in Sports and Exercise Medicine (ACPSM). Guidelines on the Management of Acute Soft Tissue Injury Using Protection Rest Ice Compression and Elevation. London: ACPSM, 2011:15-21.

4. Bring DK, Reno C, Renstrom P, et al. Joint immobilization reduces the expression of sensory neuropeptide receptors and impairs healing after tendon rupture in a rat model. J Orthop Res 2009;27:274-80.

5. Martinez DA, Vailas AC, Vanderby R Jr, et al. Temporal extracellular matrix adaptations in ligament during wound healing and hindlimb unloading. Am J Physiol Regul Integr Comp Physiol 2007;293:R1552-60.

6. Eliasson P, Andersson T, Aspenberg P. Rat Achilles tendon healing: mechanical loading and gene expression. J Appl Physiol 2009;107:399-407.

7. Bleakley CM, O'Connor SR, Tully MA, et al. Effect of accelerated rehabilitation on function after ankle sprain: randomised controlled trial. BMJ 2010;340:c1964.

8. Jones MH, Amendola AS. Acute treatment of inversion ankle sprains: immobilization versus 


\section{Editorial}

functional treatment. Clin Orthop Relat Res

2007:455:169-72

9. Kerkhoffs GM, Rowe BH, Assendelft WJ, et al. Immobilisation and functional treatment for acute lateral ankle ligament injuries in adults. Cochrane Database Syst Rev 2002;3:CD003762.
10. Khan KM, Scott A. Mechanotherapy: how physical therapists' prescription of exercise promotes tissue repair. Br J Sports Med 2009;43:247-52. 


\section{BISM PRICE needs updating, should we call the POLICE?}

C M Bleakley, P Glasgow and D C MacAuley

Br J Sports Med published online September 7, 2011

Updated information and services can be found at:

http://bjsm.bmj.com/content/early/2011/09/07/bjsports-2011-090297

\section{These include:}

References This article cites 8 articles, 6 of which you can access for free at: http://bjsm.bmj.com/content/early/2011/09/07/bjsports-2011-090297 \#BIBL

Email alerting Receive free email alerts when new articles cite this article. Sign up in the service box at the top right corner of the online article.

Topic Articles on similar topics can be found in the following collections Collections

Editor's choice (266)

Injury (906)

Trauma (807)

Drugs: musculoskeletal and joint diseases (84)

\section{Notes}

To request permissions go to:

http://group.bmj.com/group/rights-licensing/permissions

To order reprints go to:

http://journals.bmj.com/cgi/reprintform

To subscribe to BMJ go to:

http://group.bmj.com/subscribe/ 